\title{
COMPARATIVE SUPERIORITY ESTIMATES OF MORPHO- PHYSIOLOGICAL TRAITS IN NEW MAIZE CROSSES OVER THE BEST COMMERCIAL HYBRIDS UNDER DEFICIENT AND SUFFICIENT SOIL $\mathbf{N}$ \\ Abdel-Moneam, M. A. ${ }^{1}$ and F. I. Ibraheem. ${ }^{2}$ \\ 1, Agron. Dept.,Fac. of Agric., Mansoura Univ. Egypt. \\ 2, Plant. Dept.,Fac. of Sci., Mansoura Univ. Egypt.
}

\begin{abstract}
Thirteen new top crosses between B73 inbred line with some American and Egyptian inbred lines were made in 2012 season and evaluated with two commercial varieties (SC Pioneer 3084 and SC 10) under low (30 Kg N/fed) and normal (120 Kg $\mathrm{N} /$ fed) nitrogen fertilization rates in 2013 season to study the relative superior over the best commercial varieties and phenotypic correlations for morpho-physiological traits of maize under low and normal $\mathrm{N}$ conditions.

Results showed that $\mathrm{N}$-treatments mean squares were highly significant for all studied morpho-physiological traits and biological yield per plant. Also, mean squares of crosses were significant or highly significant for all studied traits under both and across $\mathrm{N}$ fertilization rates. The $\mathrm{N}$-treatments $\times$ crosses interactions mean squares were insignificant for all studied traits, except each of biological yield per plant (Bio.Y/P), relative potential photosynthesis for biological yield (RPPbio.y) and Relative potential photosynthesis for straw yield (RPPs.y), which were highly significant.

There were some new crosses manifested significant or highly significant positive or negative (desirable direction) relative superior percentages over both two commercial hybrids (SC Pioneer 3084 and SC 10) under both low and normal Nitrogen fertilization in most studied traits. For biological yield per plant and relative potential photosynthesis for biological yield (RPPBIO.Y), results showed that two crosses (B73X CML103 and B73X TZI8) recorded positive significant relative superior over both commercial hybrids SC Pioneer 3084 and SC 10 under both low and normal $\mathrm{N}$ conditions.

The phenotypic correlation coefficients varied from moderate to strong correlations between grain yield plant ${ }^{-1}$ and biological yield plant ${ }^{-1}$ and most of studied morpho-physiological traits, suggesting that, in general, to increase grain yield plant ${ }^{-1}$, selection should be carried out for these traits, especially; biological yield plant ${ }^{-1}$, low ear leaf angle (erect leaf), stem diameter (thick stalks), as well as physiological traits i.e. relative potential photosynthesis for biological yield (RPP ${ }_{\mathrm{BIO} . \mathrm{Y}}$ ) and straw yield

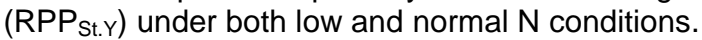

The two crosses B73X CML103 and B73X TZI8 exhibit improved morphophysiological adaptation to low $\mathrm{N}$ fertilization and better management of its internal $\mathrm{N}$ under normal $\mathrm{N}$ rate, and consequently this study recommend these crosses for large scale evaluation and commercial production.
\end{abstract}

Keyword: Maize, Relative superior, Correlation, N-fertilization

\section{INTRODUCTION}

Relative superior generally describes the superiority of $\mathrm{F} 1$ hybrids over their parental inbreds in both vigor, grain yield and many of their related traits (East, 1908; Shull 1908, 1909 and 1952; Schnell, 1961 and Reif et al., 2005). The relative superior- induced increase in grain yield in maize can be up to $200 \%$ of that of the mid-parents. Therefore, this phenomenon has been 
the driving force for improving grain yield in maize. Consequently, relative superior has been extensively studied in maize for many reasons such as (1) having better understanding of its underlying genetic, genomic and physiological mechanisms, (2) identification of genetic and environmental factors that contribute significantly to the magnitude of heterotic estimates, and (3) identification of traits generic for improvement of grain yield in maize.

Although some progress has been made in understanding the genetic and physiological basis of relative superior in maize, the full picture is far from clear. So far, three main models have been proposed for explaining this complex trait: the dominance, overdominance and epistasis hypotheses. The dominance hypothesis attribute relative superior to either partial or complete dominance of trait favorable alleles (Bruce 1910; Keeble and Pellew, 1910 and Collins, 1921) whereas the overdominance hypothesis refers relative superior to the overdominant gene action at many loci (East, 1936; Hull, 1945; Crow, 1948). On the other hand, the epistasis hypothesis attributes relative superior to epistatic interactions between non-allelic genes (Richey, 1942; Schnell and Cockerham, 1992).

Soil fertility, along with water availability, is among the critical types of abiotic stresses that have significant effects on the output of the allelic interaction and contribution to relative superior (Stupar and Springer, 2006) and consequently physiological processes and grain yield. Because of its multi-physiological functions and the high responsiveness of maize grain yield to its availability in soil, nitrogen $(\mathrm{N})$ has detrimental effects on all relative superior related parameters and consequently on maize plant growth, development and productivity (Banziger and Diallo, 2001). It has been estimated that severe shortage of soil $\mathrm{N}$ can induce more than $50 \%$ loss in grain yield (Logrono and Lothrop, 1996 and Edmeades et al., 1999). As a result, application of $\mathrm{N}$ fertilizers to corn fields has become a major component in maize production to secure grain supply to the continuously growing human population. As a results significant increase in rate of $\mathrm{N}$ application has been reported. Such extensive use of $\mathrm{N}$ fertilizers elicited many economic and health concerns (Raun and Johnson, 1999). As results, searching for new strategies for production of new high yielding maize hybrids minimal use of $\mathrm{N}$ fertilizers has been among the priorities of breeding programs worldwide. Most Egyptian farmers use low nitrogen fertilizer rates because of high price ratio between fertilizer and grain. Limited availability of nitrogen fertilizers and low purchasing power of farmers continued to be an important yield limiting factor in farmer's field (Al-Naggar et al., 2015). Breeding programs should pay attention to develop maize hybrids with high performance under variable nitrogen levels that will be of economic benefit to farmers who cannot afford to spend money for purchasing the recommended amount of nitrogen fertilizer, also will help to reduce environmental pollution associated with excessive inputs of nitrogen fertilizers, for a sustainable and environment friendly production system.

The objectives of the current study were to: (1) evaluate top crosses between inbred lines developed by authors belonging to different heterotic groups and that the public inbred line B73 for morpho-physiological traits, (2) 
compare the relative superior over commercial hybrids, (3) study the response of these heterotic estimates to both $\mathrm{N}$ stress and availability and (4) study phenotypic correlation coefficients between grain yield and other morpho-physiological traits to identify the most associated characters with yield under $\mathrm{N}$ stress.

\section{MATERIALS AND METHODS}

\section{Genetic materials:}

Thirteen new single cross maize hybrids developed by the authors were produced in 2011 at the Mansoura University, Agronomy Farm, Fac. of Agriculture along with two commercial hybrids (SC Pioneer 3084 and SC 10). These hybrids were developed by crossing the public inbred line, B73 (female parent) to nine inbred lines belonging to various heterotic groups. These parental lines included the recently released ex-pvp lines (PH207, PHJ40, and PHG47), diversity inbred lines (B97, CML103, Hp301, NC358, Tzi 8), the public inbred line MO17, and Egyptian inbred lines (Inb. 209, Sids 63, Rg 5 and Inb. 204). The American inbred lines were obtained from Dr. Stephen Moose at the University of Illinois, while the Egyptian inbred lines were obtained from the Agriculture Research Center in Egypt.

\section{Field experimental design and $\mathbf{N}$ treatment:}

In 2012 season, the field experiments was carried out at nursery of Department of Botany, Fac. Of Sci., Mansoura Univ. Mansoura, Egypt. The soil chemical analysis showed that available Nitrogen, Phosphorus and Potassium were 2.68, 7.0 and $245 \mathrm{ppm}$, respectively. The content of organic carbon was $2.68 \%$ and the $\mathrm{PH}$ was 7.9 .

For field evaluated, all plant materials were sown 24 May 2012 in two adjacent experiments, the first one received low Nitrogen fertilizer $(30 \mathrm{~kg}$ $\mathrm{N} / \mathrm{feddan}$ ) and the second was normal fertilizer application (120 kg N/feddan). A randomized complete block design with three replications was used in each experiment. Each plot consists of four rows $3 \mathrm{~m}$ long and $70 \mathrm{~cm}$ apart. Two seeds were sown per hill in spaced $25 \mathrm{~cm}$ apart. Plants were irrigated every 10-12 days. Hill was thinned to one plant hill. In each experiment $\mathrm{N}$ fertilizer was applied once down the center of row as ammonium nitrate (33.5\%)

\section{Studied traits:}

The studied morphological traits were: plant height $(\mathrm{cm})$, stem diameter $(\mathrm{cm})$, ear height $(\mathrm{cm})$, ear position (ear height/plant height), ear leaf angle, and ear leaf area $\left(\mathrm{cm}^{2}\right.$, according to Sticker, 1964). Whereas, the tested physiological traits were stay green (as percentage of green leaves number to total leaves number per plant at physiological maturity), biological yield $(\mathrm{g})$, relative photosynthesis potential for biological yield(Biological yield plant $^{-1} / \mathrm{LAI}$ ), and relative photosynthesis potential for straw yield (Straw yield plant $^{-1} /$ LAl) according to Vidovič and Pokorný (1973). 


\section{Statistical analysis:}

Analysis of variance of RCBD design was made for each experiment and their combined, and analysis of covariance between grain yield and other traits was made for each experiment.

\section{Relative superior to check hybrids:}

Relative superior was determined for individual crosses as the percentage deviation of $F_{1}$ means from commercial variety means (CV) and expressed as percentages as follows, (Fehr, 1991):

Relative superior over the C.V \% $=\left[\left(\mathrm{F}_{1}-\mathrm{CV}\right) / \mathrm{CV}\right] \times 100$

Where, $F_{1}=$ mean performance of $F_{1}$ hybrid and $C V=$ mean of check or commercial variety. The significance of relative superior effect for $F_{1}$ values from the commercial variety was tested according to the following formula:

LSD for relative superior $(\mathrm{CV})=\mathrm{t}_{0.05}$ or $0.01 \times(2 \mathrm{MSe} / \mathrm{r})^{1 / 2}$

Where, $\mathrm{t}=$ tabulated "t" value at a stated level of probability for the experimental error degree of freedom, MSe = Mean squares of the experimental error from the analysis of variance and $r=$ Number of replicates.

\section{RESULTS AND DISCUSSION}

The superiority of $F_{1}$ hybrids in yield and vigor over their inbred parents was reported early in the twentieth century (Shull, 1908). Since then, relative superior has been the main stimulation for maize development as well as the major reason for the continuous breeding efforts for yield improvement in maize and many other crops. Although great progress has been made in understanding the genetic and physiological basis of relative superior, the full picture is far from clear (Schnable and Springer, 2013 and $\mathrm{Fu}$ et al., 2014a\&b). In addition, relatively little information about the biochemical, physiological, and molecular basis of this event is available. As a result, scientists have been designing experiments to dissect and investigate different mechanisms of relative superior. Over the years, the majority of the scientific community has attributed relative superior to dominance or over dominance of grain yield- and vigor- favoring alleles, and recently epistasis and linkage have been reported as major contributors (Hochholdinger and Hoecker, 2007). One common theme throughout the last century has been that no one hypothesis of relative superior holds true for every experiment or every organism (Leyla Cesurer et al., 2002; Schnable and Springer, 2013). In the current study, we developed thirteen new maize hybrids with a common female parent (B73) to test the impact of different genomes imported by different male maize genotypes of different climatic zones into the B73 genetic background on relative superior and consequently yield. This was carried out by studying grain yield and its related phenotypic, genotypic and physiological traits under $\mathrm{N}$ insufficient and sufficient conditions.

\section{Analysis of variance:}

Analysis of variance of the two $\mathrm{N}$ levels and across them for the studied traits is presented in Table 1. Analysis of variance of single and combined analysis showed that $\mathrm{N}$-treatments mean squares were highly significant for all studied morpho-physiological traits and biological yield per 
plant, indicating significant differences between the two nitrogen fertilization rates for all studied characters.

Table (1): Mean squares from analysis of variance for morphophysiological traits and biological yield per plant under both and across Nitrogen fertilization levels.

\begin{tabular}{|c|c|c|c|c|c|c|c|c|}
\hline \multirow[b]{2}{*}{ S.O.V } & \multicolumn{2}{|c|}{ df } & \multicolumn{3}{|c|}{ Plant height } & \multicolumn{3}{|c|}{ Stem diameter } \\
\hline & Single & $\begin{array}{c}\text { Comb } \\
\text {. }\end{array}$ & Low N & $\underset{\mathrm{N}}{\text { Normal }}$ & Comb. & Low N & $\underset{\mathrm{N}}{\text { Normal }}$ & Comb. \\
\hline $\begin{array}{l}\mathrm{N}- \\
\text { treatments }\end{array}$ & - & 1 & - & - & $4494.4^{* *}$ & - & - & $10.68^{\star *}$ \\
\hline Rep/N & - & 4 & - & - & 19.067 & - & - & 0.476 \\
\hline Crosses & 14 & 14 & $1983.1^{\star \star}$ & $2114^{\star \star}$ & $4023.5^{\star \star}$ & $20.43^{\star \star}$ & $20.84^{\star \star}$ & $41.18^{\star \star}$ \\
\hline $\mathrm{N} \times \mathrm{C}$ & - & 14 & - & - & 73.686 & - & - & 0.088 \\
\hline Error & 28 & 56 & 69.405 & 74.086 & 71.745 & 0.738 & 1.075 & 0.906 \\
\hline \multirow{2}{*}{ S.O.V } & \multicolumn{2}{|c|}{$\mathrm{df}$} & \multicolumn{3}{|c|}{ Ear height } & \multicolumn{3}{|c|}{ Ear position } \\
\hline & Single & Comb. & Low $\mathrm{N}$ & Normal N & Comb. & Low $\mathrm{N}$ & Normal N & Comb. \\
\hline $\begin{array}{l}\mathrm{N}- \\
\text { treatments }\end{array}$ & - & 1 & - & - & $4410.0^{\star *}$ & - & - & $0.012^{\star *}$ \\
\hline Rep/N & - & 4 & - & - & 33.056 & - & - & 0.001 \\
\hline Crosses & 14 & 14 & $1149^{* *}$ & $1642^{* *}$ & $2719^{\star *}$ & $0.004^{* *}$ & $0.007^{* *}$ & $0.011^{* *}$ \\
\hline $\mathrm{N} \times \mathrm{C}$ & - & 14 & - & - & 73.09 & - & - & 0.001 \\
\hline Error & 28 & 56 & 97.10 & 32.10 & 64.603 & 0.001 & 0.001 & 0.001 \\
\hline \multirow{2}{*}{ S.O.V } & \multicolumn{2}{|c|}{$\mathrm{df}$} & \multicolumn{3}{|c|}{ Ear leaf angle } & \multicolumn{3}{|c|}{ Ear leaf area } \\
\hline & Single & Comb. & Low $\mathrm{N}$ & Normal N & Comb. & Low $\mathrm{N}$ & Normal N & Comb. \\
\hline \begin{tabular}{|l|}
$\mathrm{N}-$ \\
treatments
\end{tabular} & - & 1 & - & - & $160.0^{\star *}$ & - & - & $55003^{* *}$ \\
\hline Rep/N & - & 4 & - & - & 5.733 & - & - & 974.9 \\
\hline Crosses & 14 & 14 & $73.33^{\star \star}$ & $94.05^{\star \star}$ & $158.79^{* *}$ & $37987^{\star \star}$ & $42194^{\star *}$ & $77230^{\star *}$ \\
\hline $\mathrm{NXC}$ & - & 14 & - & - & 8.595 & - & - & 2952.1 \\
\hline Error & 28 & 56 & 13.70 & 6.219 & 9.96 & 2132.9 & 2191.1 & 2161.99 \\
\hline \multirow{2}{*}{ S.O.V } & \multicolumn{2}{|c|}{$\mathrm{df}$} & \multicolumn{3}{|c|}{ Stay green $\%$} & \multicolumn{3}{|c|}{ Biological yield plant $^{-1}$} \\
\hline & \begin{tabular}{|l|} 
Single \\
\end{tabular} & Comb. & Low $\mathrm{N}$ & Normal N & Comb. & Low N & Normal N & Comb. \\
\hline \begin{tabular}{|l|}
$\mathrm{N}-$ \\
treatments
\end{tabular} & - & 1 & - & - & $538.56^{\star *}$ & - & - & $227949^{* *}$ \\
\hline Rep/N & - & 4 & - & - & 33.146 & - & - & 30.235 \\
\hline Crosses & 14 & 14 & $70.15^{\star *}$ & $81.69^{*}$ & $140.93^{\star *}$ & $51592^{\star *}$ & $81465^{\star *}$ & $122502^{\star *}$ \\
\hline $\mathrm{N} \times \mathrm{C}$ & - & 14 & - & - & 10.906 & & & $10555^{\star \star}$ \\
\hline Error & 28 & 56 & 18.45 & 37.03 & 27.738 & 44.753 & 24.614 & 34.684 \\
\hline \multirow[t]{2}{*}{ S.O.V } & \multicolumn{2}{|c|}{ Df } & \multicolumn{3}{|c|}{$\begin{array}{c}\text { Relative potential } \\
\text { photosynthesis for biological } \\
\text { yield (RPP } \text { Bio.Y }\end{array}$} & \multicolumn{3}{|c|}{$\begin{array}{c}\text { Relative potential } \\
\text { photosynthesis for straw yield } \\
\left(\mathrm{RPP}_{\mathrm{St.Y}}\right)\end{array}$} \\
\hline & Single & Comb. & Low N & Normal N & Comb. & Low N & Normal N & Comb. \\
\hline $\begin{array}{l}\mathrm{N}- \\
\text { treatments }\end{array}$ & - & 1 & - & - & $1719.5^{\star *}$ & - & - & $407.46^{\star *}$ \\
\hline Rep/N & - & 4 & - & - & 21.140 & - & - & 7.505 \\
\hline Crosses & 14 & 14 & $847.8^{\star \star}$ & $864.9^{\star \star}$ & $1503.9^{* *}$ & $202.15^{\star \star}$ & $490.7^{\star \star}$ & $610.2^{\star \star}$ \\
\hline $\mathrm{NXC}$ & - & 14 & - & - & $208.78^{\star \star}$ & - & - & $82.66^{\star \star}$ \\
\hline Error & 28 & 56 & 32.119 & 33.836 & 32.977 & 16.268 & 13.545 & 14.91 \\
\hline
\end{tabular}

$\left({ }^{*}\right)$ and $\left(^{* *}\right)$ significant at 0.05 and 0.01 levels probability, respectively.

Also, mean squares of crosses were significant or highly significant for all studied traits under both and across $\mathrm{N}$ fertilization rates and their combined 
analysis, indicating significant genotypic differences among the studied crosses. The $\mathrm{N}$-treatments $\times$ crosses interactions mean squares were insignificant for all studied traits, except each of biological yield per plant (Bio.Y/P), relative potential photosynthesis for biological yield (RPPbio.y) and Relative potential photosynthesis for straw yield (RPPs.y), indicating that these crosses did not differ by both environmental changes (Nitrogen rates) for the exceptional cases effected significantly by nitrogen changes.

Plant height: Plant height of maize plants are preferred as shortness because plants with greater height are likely to lodge during wind storm. Therefore, the plant height relative superior in the negative direction is desirable. Results in Table 2 revealed that all studied cross combinations manifested negative significant or highly significant relative superior over the commercial check variety SC Pioneer 3084 , which ranged from $-4.52 \%$ for cross no. 13 (B73X Inb. 204) to $-33.90 \%$ for cross no. 1 (B73X Phg 47) under low $\mathrm{N}$ application. However, nine cross combinations showed negative significant or highly significant relative superior over check variety SC 10 , which ranged from $-4.85 \%$ for cross no. 8 to $-29.09 \%$ for cross no. 1 (B73X Phg 47) under low $N$ environment. However, under normal N, 10 crosses manifested negative significant or highly significant relative superior over both the two check varieties SC Pioneer 3084 and SC10 for plant height (shortness), and the highest percentages of superiority (-30.83 and $-30.44 \%)$ were recorded by cross no. 1 (B73X Phg 47). The reason for this great relative superior in plant height could be overdominance, the accumulation of dominant alleles in different loci or epistasis (Hallauer and Miranda, 1981). Similar results were obtained by Abd El-Aty and Katta (2002); Saleh et al. (2002); Langade et al. (2013) and Abdel-Moneam et al. (2014).

Table (2) : Estimates of relative superior over commercial varieties (SC Pioneer 3084 and SC 10) of $13 F_{1}$ single crosses for plant height and stem diameter under low and normal nitrogen.

\begin{tabular}{|c|c|c|c|c|c|c|c|c|}
\hline \multirow{3}{*}{$\begin{array}{l}\text { Traits } \\
\text { Crosses }\end{array}$} & \multicolumn{4}{|c|}{ Plant height, cm } & \multicolumn{4}{|c|}{ Stem diameter, cm } \\
\hline & \multicolumn{2}{|c|}{ Low N } & \multicolumn{2}{|c|}{ Normal N } & \multicolumn{2}{|c|}{ Low N } & \multicolumn{2}{|c|}{ Normal N } \\
\hline & SC 3084 & SC10 & SC 3084 & SC10 & SC 3084 & SC10 & SC 3084 & SC10 \\
\hline 1-B73X PHG47 & $-33.90^{* *}$ & $-29.09^{* *}$ & $-30.83^{* *}$ & $-30.44^{\star *}$ & $-11.98^{\star \star}$ & $-14.42^{\star \star}$ & $-13.74^{\star *}$ & $-15.70^{\star \star}$ \\
\hline 2-B73X B97 & $-17.51^{* *}$ & $-11.52^{* \star}$ & $-17.13^{* *}$ & $-16.67^{\star *}$ & $-15.12^{* *}$ & $-17.48^{* *}$ & $-12.77^{* *}$ & $-14.76^{\star *}$ \\
\hline 3-B73X PHJ40 & $-24.86^{\star *}$ & $-19.39^{\star \star}$ & $-23.76^{\star \star}$ & $-23.33^{\star \star}$ & $-24.39^{* *}$ & $-26.49^{\star *}$ & $-25.14^{* \star}$ & $-26.84^{\star *}$ \\
\hline 4-B73X PH207 & $-18.64^{\star *}$ & $-12.73^{\star \star}$ & $-12.15^{\star \star}$ & $-11.67^{\star \star}$ & $-29.53^{\star \star}$ & $-31.48^{\star \star}$ & $-30.08^{\star *}$ & $-31.68^{\star \star}$ \\
\hline 5-B73X HP301 & $-13.56^{\star *}$ & $-7.27^{\star \star}$ & $-6.63^{\star \star}$ & $-6.11^{*}$ & $-13.98^{\star \star}$ & $-16.36^{\star \star}$ & $-14.83^{\star \star}$ & $-16.78^{\star \star}$ \\
\hline 6-B73X CML103 & $-12.99^{* *}$ & $-6.67^{* \star}$ & $-9.94^{* *}$ & $-9.44^{\star *}$ & -3.85 & $-6.52^{*}$ & -4.26 & -6.44 \\
\hline 7-B73X TZI8 & $-5.08^{*}$ & 1.82 & -4.42 & -3.89 & $6.70^{*}$ & 3.74 & 4.80 & 2.42 \\
\hline 8-B73X NC358 & $-11.30^{* *}$ & $-4.85^{\star}$ & $-8.84^{\star *}$ & $-8.33^{\star \star}$ & -1.43 & -4.16 & -1.92 & -4.16 \\
\hline 9-B73X MO17 & $-16.38^{* *}$ & $-10.30^{* *}$ & $-16.02^{* *}$ & $-15.56^{\star *}$ & $-23.26^{\star *}$ & $-25.38^{* *}$ & $-22.53^{* *}$ & $-24.29^{* *}$ \\
\hline 10-B73X Inb209 & $-7.34^{\star *}$ & -0.61 & $-6.08^{\star \star}$ & $-5.56^{*}$ & $-15.27^{\star \star}$ & $-17.61^{\star \star}$ & $-15.94^{\star \star}$ & $-17.85^{\star *}$ \\
\hline 11-B73X Sids63 & $-6.78^{\star \star}$ & 0.00 & -2.21 & -1.67 & 0.71 & -2.08 & 0.27 & -2.01 \\
\hline 12-B73X Rg5 & $-10.17^{\star \star}$ & -3.64 & $-7.18^{\star *}$ & $-6.67^{\star \star}$ & $-9.70^{\star \star}$ & $-12.20^{\star \star}$ & $-10.58^{\star \star}$ & $-12.62^{\star \star}$ \\
\hline 13-B73X Inb.204 & $-4.52^{*}$ & 2.42 & -2.76 & -2.22 & 2.28 & -0.55 & 0.41 & -1.88 \\
\hline \begin{tabular}{|l|l|} 
LSD & at 0.05 \\
\end{tabular} & \multicolumn{2}{|c|}{12.842} & \multicolumn{2}{|c|}{14.590} & \multicolumn{2}{|c|}{1.524} & \multicolumn{2}{|c|}{1.677} \\
\hline at 0.01 & \multicolumn{2}{|c|}{17.232} & \multicolumn{2}{|c|}{19.578} & \multicolumn{2}{|c|}{2.045} & \multicolumn{2}{|c|}{2.251} \\
\hline
\end{tabular}

*and ${ }^{* *}$ significant at 0.05 and 0.01 level of probability, respectively. 
Stem diameter: Positive relative superior for stem diameter is important because it is an effective yield related parameter. Results given in Table 2 revealed that most crosses had negative highly significant relative superior over both two check hybrids SC Pioneer 3084 and SC 10 under both low and normal N conditions. There was one cross (B73X TZ18) recorded significant positive relative superior over SC Pioneer $3084(6.70 \%)$ under low N, and positive estimates over SC 10 under low $\mathrm{N}$ and over both hybrids under both $\mathrm{N}$ levels, but did not reach to significant level.

Ear height: The height of the main ear is a very important characteristic for breeding. The higher it is, the more ears can develop from the nodes below. However, if it is too high the weight of the ear may bend the stalk or even break it. Although lower ear height is unfavorable for yield and makes harvesting difficult, it does protect the stalk from excessive weight. Attempts have been made to breed in both directions, but practical experience shows that the ideal height is somewhere in between - neither too high, nor too low. It is extremely important for the ears to be at the same height within a population. In order to fulfil this requirement, homogenous populations or varieties are needed. Hybrids are usually as balanced as inbred lines, because in the $F_{1}$ generation Mendel's rule of uniformity is predominant. As a result of inbreeding, plant height and ear height decrease, and the population becomes more and more homogeneous, until it reaches the "inbred minimum". Producing hybrids by crossing has the opposite effect: plant height and ear height increases, but only in the first $\left(F_{1}\right)$ generation (Györffy et al., 1965). Ear height on maize plant is preferred low ear placement because plants with greater ear height are likely to lodge during wind storm especially during irrigation practice. Therefore, the ear height relative superior in the negative direction is desirable. Results given in Table 3 revealed that twelve and six cross combinations manifested negative significant or highly significant relative superior over the two check varieties SC Pioneer 3084 and SC 10, respectively, under low $\mathrm{N}$ condition. And, the highest percentages $(-45.00 \%$ and $-40.22 \%)$ were recorded by cross no. 1 (B73X PHG 47 ) over SC Pioneer 3084 and SC10, respectively. Whereas under normal N, there were eleven and nine cross combinations manifested negative significant or highly significant relative superior over both the two check varieties SC Pioneer 3084 and SC10 for ear height, and also the highest percentages $(-44.86 \%$ and $-40.40 \%)$ were recorded by cross no. 1 (B73X PHG 47 ) over SC Pioneer 3084 and SC10, respectively.

Ears position (\%): Low ear placement is preferred on maize plant because plants with greater ear height lead to lodge during wind storm especially during irrigation practice. Therefore, the ear position relative superior in the negative direction is desirable. Results given in Table 3 revealed that seven and six cross combinations showed negative significant or highly significant relative superior over the two check varieties SC Pioneer 3084 and SC 10 under low $\mathrm{N}$ condition, respectively. The highest percentages $(-17.11 \%$ and 15.62\%) were recorded by cross no. 1 (B73X PHG 47) over SC Pioneer 3084 
and SC10, respectively. Whereas, under normal $\mathrm{N}$, there were eight and one cross combinations manifested negative significant or highly significant relative superior over two check varieties SC Pioneer 3084 and SC10, respectively. The highest percentages $(-19.83 \%$ and $-14.47 \%)$ were recorded by cross no. 1 (B73X Phg 47) over SC Pioneer 3084 and SC10, respectively. These results are in agreement with those obtained by Abd El -Aty and Katta (2002); Reddy and Ahuja (2004); Pilar et al. (2006); Shalim et al.(2006) and Abdel-Moneam et al. (2014)

Table (3): Estimates of relative superior over commercial varieties (SC Pioneer 3084 and SC 10) of $13 F_{1}$ single crosses for ear height and ear position under low and normal nitrogen conditions.

\begin{tabular}{|c|c|c|c|c|c|c|c|c|}
\hline & \multicolumn{4}{|c|}{ Ear height, cm } & \multicolumn{4}{|c|}{ Ear position } \\
\hline & \multicolumn{2}{|c|}{ Low N } & \multicolumn{2}{|c|}{ Normal N } & \multicolumn{2}{|c|}{ Low N } & \multicolumn{2}{|c|}{ Normal N } \\
\hline & SC 3084 & SC10 & SC 3084 & SC10 & SC 3084 & SC10 & SC 3084 & SC10 \\
\hline 1-B73X PHG47 & $-45.00^{\star *}$ & $-40.22^{\star \star}$ & $-44.86^{\star \star}$ & $-40.40^{\star *}$ & $-17.11^{\star \star}$ & $-15.62^{\star *}$ & $-19.83^{\star \star}$ & $-14.47^{\star \star}$ \\
\hline 2-B73X B97 & $-27.00^{\star *}$ & $-20.65^{\star \star}$ & $-28.04^{* *}$ & $-22.22^{\star *}$ & $-11.82^{\star}$ & $-10.23^{*}$ & $-13.05^{\star \star}$ & -7.23 \\
\hline 3-B73X PHJ40 & $-36.00^{\star *}$ & $-30.43^{\star \star}$ & $-34.58^{\star *}$ & $-29.29^{\star *}$ & $-14.81^{\star *}$ & $-13.29^{\star *}$ & $-14.07^{\star *}$ & -8.32 \\
\hline 4-B73X PH207 & $-24.00^{\star *}$ & $-17.39^{* *}$ & $-21.50^{* *}$ & $-15.15^{\star *}$ & -7.05 & -5.39 & $-10.17^{*}$ & -4.16 \\
\hline 5-B73X HP301 & $-12.00^{\star \star}$ & -4.35 & 0.93 & $9.09^{* *}$ & 1.76 & 3.59 & 8.47 & $15.73^{\star *}$ \\
\hline 6-B73X CML103 & -7.00 & 1.09 & -0.93 & $7.07^{*}$ & 6.35 & 8.26 & $10.68^{*}$ & $18.08^{* *}$ \\
\hline 7-B73X TZI8 & $-10.00^{*}$ & -2.17 & $-5.61^{*}$ & 2.02 & -4.76 & -3.05 & -1.19 & 5.42 \\
\hline 8-B73X NC358 & $-15.00^{\star *}$ & -7.61 & $-14.95^{\star *}$ & $-8.08^{\star \star}$ & -4.76 & -3.05 & -6.78 & -0.54 \\
\hline 9-B73X MO17 & $-27.00^{\star \star}$ & $-20.65^{\star \star}$ & $-25.23^{\star \star}$ & $-19.19^{\star \star}$ & $-13.05^{\star \star}$ & $-11.49^{*}$ & $-10.68^{*}$ & -4.70 \\
\hline 10-B73X Inb209 & $-21.00^{\star *}$ & $-14.13^{\star \star}$ & $-14.95^{\star *}$ & $-8.08^{\star \star}$ & $-14.81^{\star \star}$ & $-13.29^{\star *}$ & $-9.66^{*}$ & -3.62 \\
\hline 11-B73X Sids63 & $-16.00^{\star *}$ & -8.70 & $-16.82^{* *}$ & $-10.10^{* *}$ & $-10.05^{*}$ & -8.44 & $-14.75^{\star *}$ & -9.04 \\
\hline 12-B73X Rg5 & $-15.00^{\star *}$ & -7.61 & $-14.02^{* *}$ & $-7.07^{*}$ & -5.29 & -3.59 & -7.29 & -1.08 \\
\hline 13-B73X Inb.204 & $-15.00^{* *}$ & -7.61 & $-12.15^{\star *}$ & -5.05 & \begin{tabular}{|l|}
$-11.29^{*}$ \\
\end{tabular} & $-9.69^{*}$ & $-9.66^{*}$ & -3.62 \\
\hline LSD at 0.05 & \multicolumn{2}{|c|}{14.825} & \multicolumn{2}{|c|}{8.823} & \multicolumn{2}{|c|}{0.052} & \multicolumn{2}{|c|}{0.052} \\
\hline \begin{tabular}{|l|} 
at 0.01 \\
\end{tabular} & \multicolumn{2}{|c|}{19.893} & \multicolumn{2}{|c|}{11.840} & \multicolumn{2}{|c|}{0.070} & \multicolumn{2}{|c|}{0.070} \\
\hline
\end{tabular}

${ }^{*}$ and ${ }^{* \star}$ significant at 0.05 and 0.01 level of probability, respectively.

Ear leaf angle: Breeding for erect maize canopies will be of great importance as far as maize productivity is concerned. Pendleton et al. (1968) found a yield increase of $14 \%$ when leaves above the ear of pioneer 3306 were tied upright during pollination at about 10 。 from vertical and maintained in this position until harvest compared with the untreated check. Loomis and Cannor (1992) noted that highly productive canopies have the characteristics of erective leaves. Decreased leaf angle to the vertical is thus associated with concomitant increase in light penetration. Horizontally-oriented leaves will shade each other, thus decreasing the plant net photosynthesis. If the penetration of light into canopy increases in proportion to the decrease of the leaf angle to the vertical, there should be an increase in photosynthesis. Greater photosynthesis means increase in production of dry matter, part of which should be converted to grain. Therefore, breeding for more erect oriented leaves may increase the net photosynthesis and finally the yield of the plant. Therefore, ear leaf angle on maize plant is preferred low (leaf erect) because erect leaves allows light radiation to intercept and absorb efficiently 
by all leaves of plant and so increasing photosynthesis process. So, the ear leaf angle relative superior in the negative direction is desirable.

Under limited soil $\mathrm{N}$, our results in Table 4 revealed that only cross no. 8 (B73X NC358) manifested negative non-significant relative superior over the two check variety SC Pioneer $3084(-5.80 \%)$ and negative significant relative superior over SC $10(-23.53 \%)$. Whereas, under sufficient soil $\mathrm{N}$, three crosses no. 8, 7 and 6 (B73X NC358, B73X LIZ21 and B73X CML104) showed negative significant or highly significant relative superior $(-26.88$, 19.35 and $-17.20 \%$ ) over SC Pioneer 3084 , respectively, whereas only the cross combination no. 8 (B73X NC358) showed negative highly significant relative superior over SC10 (-22.73\%) for ear leaf angle trait. Our results thus suggest that hybrids B73X NC358, B73X LIZ21 and B73X CML104 attained the highest negative heterotic estimates on leaf angle and thus are expected to be more efficient in light absorption and photosynthesis processes which must likely be reflected in grain yield.

Ear leaf area: Ear leaf area on maize plant is preferred high because large leaves allows light radiation to intercept and absorb efficiently and so increasing photosynthesis process. Therefore, the ear leaf area relative superior in the positive direction is desirable. Results given in Table 4 revealed that all crosses manifested negative significant or highly significant relative superior over the two check varieties SC Pioneer 3084 and SC 10 under both low and normal $\mathrm{N}$ conditions. Results showed that no crosses recorded positive relative superior estimates over both check varieties under both low and normal $\mathrm{N}$ levels.

Table (4): Estimates of relative superior over commercial varieties (SC Pioneer 3084 and SC 10) of $13 F_{1}$ single crosses for ear leaf angle and ear leaf area under low and normal nitrogen conditions.

\begin{tabular}{|c|c|c|c|c|c|c|c|c|}
\hline \multirow{3}{*}{\begin{tabular}{|l} 
Traits \\
Crosses
\end{tabular}} & \multicolumn{4}{|c|}{ Ear leaf angle } & \multicolumn{4}{|c|}{ Ear leaf area, $\mathrm{cm}^{2}$} \\
\hline & \multicolumn{2}{|c|}{ Low N } & \multicolumn{2}{|c|}{ Normal N } & \multicolumn{2}{|c|}{ Low N } & \multicolumn{2}{|c|}{ Normal N } \\
\hline & SC 3084 & SC10 & SC 3084 & SC10 & SC 3084 & SC10 & SC 3084 & SC10 \\
\hline 1-B73X PHG47 & $37.68^{\star *}$ & 11.77 & 7.53 & 13.64 & $-34.03^{* *}$ & $-32.20^{\star *}$ & $-31.29^{\star *}$ & $-28.66^{\star *}$ \\
\hline 2-B73X B97 & $30.43^{*}$ & 5.88 & 2.15 & 7.96 & $-23.37^{* *}$ & $-21.24^{\star *}$ & $-28.55^{\star *}$ & $-25.81^{\star *}$ \\
\hline 3-B73X PHJ40 & $66.67^{\star \star}$ & $35.29^{\star \star}$ & $31.18^{\star \star}$ & $38.64^{\star \star}$ & $-40.50^{\star \star}$ & $-38.85^{\star \star}$ & $-41.77^{\star \star}$ & $-39.54^{\star *}$ \\
\hline 4-B73X PH207 & $46.38^{\star \star}$ & 18.83 & $35.48^{\star \star}$ & $43.18^{\star \star}$ & $-46.15^{\star \star}$ & $-44.66^{\star \star}$ & $-48.42^{\star \star}$ & $-46.45^{\star \star}$ \\
\hline 5-B73X HP301 & $59.42^{\star \star}$ & $29.41^{\star \star}$ & $23.65^{\star \star}$ & $30.68^{\star \star}$ & $-21.89^{* *}$ & $-19.72^{\star \star}$ & $-22.55^{\star \star}$ & $-19.58^{\star \star}$ \\
\hline 6-B73X CML103 & 5.80 & -14.12 & $-17.20^{*}$ & -12.50 & -7.36 & -4.79 & -8.50 & -4.99 \\
\hline 7-B73X TZI8 & 1.45 & -17.65 & $-19.35^{\star}$ & -14.77 & $-26.52^{* *}$ & $-24.48^{\star \star}$ & $-12.48^{\star *}$ & $-9.12^{*}$ \\
\hline 8-B73X NC358 & -5.80 & $-23.53^{*}$ & $-26.88^{\star \star}$ & $-22.73^{\star \star}$ & $-23.68^{* \star}$ & $-21.56^{\star \star}$ & $-26.23^{\star *}$ & $-23.40^{\star \star}$ \\
\hline 9-B73X MO17 & $30.43^{\star *}$ & 5.88 & 7.53 & 13.64 & $-31.36^{\star *}$ & $-29.45^{\star *}$ & $-25.01^{\star *}$ & $-22.13^{\star *}$ \\
\hline 10-B73X Inb209 & $30.43^{\star \star}$ & 5.88 & 0.00 & 5.68 & $-24.19^{* \star}$ & $-22.09^{\star \star}$ & $-20.99^{\star *}$ & $-17.96^{\star \star}$ \\
\hline 11-B73X Sids63 & 15.94 & -5.88 & -1.07 & 4.55 & $-13.15^{\star}$ & -10.74 & $-18.93^{\star *}$ & $-15.82^{\star \star}$ \\
\hline 12-B73X Rg5 & 15.94 & -5.88 & -7.53 & -2.27 & $-16.52^{\star \star}$ & $-14.20^{*}$ & $-19.93^{\star *}$ & $-16.86^{\star \star}$ \\
\hline 13-B73X Inb.204 & 11.60 & -9.41 & -13.98 & -9.09 & -8.97 & -6.44 & $-13.05^{\star *}$ & $-9.72^{*}$ \\
\hline \begin{tabular}{|lll} 
LSD & at 0.05 \\
\end{tabular} & \multicolumn{2}{|c|}{5.777} & \multicolumn{2}{|c|}{4.615} & \multicolumn{2}{|c|}{96.500} & \multicolumn{2}{|c|}{78.511} \\
\hline at 0.01 & \multicolumn{2}{|c|}{7.752} & \multicolumn{2}{|c|}{6.192} & \multicolumn{2}{|c|}{129.491} & \multicolumn{2}{|c|}{105.351} \\
\hline
\end{tabular}

${ }^{*}$ and ${ }^{\star *}$ significant at 0.05 and 0.01 level of probability, respectively. 
Stay green \%: Stay green on maize plant at physiological maturity date is preferred high percentage because it can be used for animal feed after harvest, i. e. we will get a dual-purpose plant (grain yield at maturity and at the same time the rest of the plant is used as green fodder). Therefore, the stay green relative superior in the positive direction is desirable. Results given in Table 5 showed that no crosses manifested positive significant relative superior over the check hybrid SC Pioneer 3084 under both low and normal $\mathrm{N}$ conditions. On the other hand, there were ten and six cross combinations manifested positive significant or highly significant relative superior over the check hybrid SC10 for stay green under low and normal N, respectively. The highest percentages $\left(33.65^{\star *}\right.$ and $\left.35.13^{* *}\right)$ were recorded by cross no. 8 (B73X NC358) over SC10 under low and normal N, respectively.

Table (5) : Estimates of relative superior over commercial varieties (SC Pioneer 3084 and SC 10) of $13 F_{1}$ single crosses for stay green $\%$ and biological yield plant ${ }^{-1}$ under low and normal nitrogen conditions.

\begin{tabular}{|c|c|c|c|c|c|c|c|c|}
\hline \multirow{3}{*}{$\begin{array}{c}\text { Traits } \\
\text { Crosses }\end{array}$} & \multicolumn{4}{|c|}{ Stay green \% } & \multicolumn{4}{|c|}{ Biological yield plant $^{-1}, \mathbf{g}$} \\
\hline & \multicolumn{2}{|c|}{ Low N } & \multicolumn{2}{|c|}{ Normal N } & \multicolumn{2}{|c|}{ Low N } & \multicolumn{2}{|c|}{ Normal N } \\
\hline & SC 3084 & SC10 & SC 3084 & SC10 & SC 3084 & SC10 & SC 3084 & SC10 \\
\hline 1-B73X PHG47 & $-14.32^{*}$ & 7.03 & -3.32 & 13.23 & $-27.79^{\star *}$ & $-21.27^{* *}$ & $-18.62^{* *}$ & $-28.99^{\star *}$ \\
\hline 2-B73X B97 & -5.30 & $18.30^{*}$ & 3.90 & $21.68^{\star}$ & $-27.86^{\star \star}$ & $-21.34^{\star *}$ & $-20.08^{\star *}$ & $-30.27^{\star \star}$ \\
\hline 3-B73X PHJ40 & $-20.44^{\star *}$ & -0.61 & $-20.08^{*}$ & -6.40 & $-53.20^{\star *}$ & $-48.97^{* *}$ & $-43.74^{\star *}$ & $-50.91^{\star *}$ \\
\hline 4-B73X PH207 & -3.69 & $20.31^{*}$ & 7.89 & $26.36^{\star *}$ & $-47.64^{\star *}$ & $-42.90^{* *}$ & $-43.34^{\star *}$ & $-50.56^{\star \star}$ \\
\hline 5-B73X HP301 & -6.21 & $17.17^{*}$ & -5.13 & 11.11 & $-41.31^{* *}$ & $-36.00^{* *}$ & $-30.50^{* *}$ & $-39.36^{\star *}$ \\
\hline 6-B73X CML103 & -8.40 & & -6.01 & 10.08 & $27.51^{\star \star}$ & $39.03^{\star \star}$ & $26.43^{\star *}$ & $10.32^{\star *}$ \\
\hline 7-B73X TZI8 & 2.59 & $28.16^{\star \star}$ & 1.40 & 18.75 & $11.74^{\star \star}$ & $21.84^{\star *}$ & $50.53^{* *}$ & $31.35^{\star *}$ \\
\hline 8-B73X NC358 & 6.99 & $33.65^{\star \star}$ & 15.39 & $35.13^{* *}$ & -1.30 & $7.62^{\star *}$ & 0.26 & $-12.51^{\star *}$ \\
\hline 9-B73X MO17 & -3.69 & $20.31^{*}$ & -0.10 & 16.99 & $-45.54^{* *}$ & $-40.62^{* *}$ & $-28.00^{* *}$ & $-37.17^{\star \star}$ \\
\hline 10-B73X Inb209 & -0.34 & $24.50^{\star *}$ & 5.83 & $23.94^{*}$ & $-42.37^{* *}$ & $-37.16^{\star *}$ & $-32.99^{* *}$ & $-41.53^{\star *}$ \\
\hline 11-B73X Sids63 & 4.79 & $30.90^{* *}$ & 1.40 & 18.75 & $-22.61^{* *}$ & $-15.61^{* *}$ & $26.60^{* *}$ & $10.47^{* *}$ \\
\hline 12-B73X Rg5 & 2.45 & $27.98^{\star \star}$ & 3.10 & $20.74^{\star}$ & $-28.18^{\star \star}$ & $-21.69^{\star *}$ & $-24.84^{\star \star}$ & $-34.41^{\star \star}$ \\
\hline 13-B73X Inb.204 & 2.59 & $28.16^{\star *}$ & 4.90 & $22.85^{\star}$ & $-14.72^{* \star}$ & $-7.01^{* *}$ & 0.26 & $-12.51^{* *}$ \\
\hline LSD at 0.05 & \multicolumn{2}{|c|}{7.120} & \multicolumn{2}{|c|}{9.775} & \multicolumn{2}{|c|}{10.540} & \multicolumn{2}{|c|}{7.675} \\
\hline at 0.01 & \multicolumn{2}{|c|}{9.554} & \multicolumn{2}{|c|}{13.117} & \multicolumn{2}{|c|}{14.143} & \multicolumn{2}{|c|}{10.299} \\
\hline
\end{tabular}

${ }^{*}$ and ${ }^{* *}$ significant at 0.05 and 0.01 level of probability, respectively.

Biological yield plant $^{-1}$ : Biological yield was found to be the most influential factor affecting grains per plant and consequently grain yield of maize cultivars, and high yielding cultivars of maize can only be achieved by increasing plant biomass (Kazem Ghassemi-Golezani, 2012). Results given in Table 5 revealed that positive (desirable direction) highly significant relative superior percentages over commercial check hybrids SC Pioneer 3084 and SC 10 were recorded in two and three crosses, respectively, under low $\mathrm{N}$ conditions. The highest percentages were recorded by cross no. 6 (B73X CML103) (27.51\% over SC3084 and $39.03 \%$ over SC 10) followed by cross no. 7 (B73X TZI8) (11.74\% over SC3084 and $21.84 \%$ over SC 10$)$. Under 
normal N conditions, three crosses (B73X CML103, B73X TZI8, B73X NC358 and B73X Sids63) showed positive significant relative superior over both commercial hybrids SC Pioneer 3084 and SC 10 . cross no.7 (B73X TZI8) gave the highest estimates of relative superior $(50.53 \%$ over SC3084 and $31.5 \%$ over SC 10 ).

The obvious differences in heterotic estimates of biological yield among the new hybrids under both low and normal $\mathrm{N}$ conditions suggest different physiological processes-limiting biological yield such as photosynthetic capabilities, dry matter accumulation and partitioning. In addition, the current results also suggest different mechanisms of interaction between parent's genomes. Consistent with this hypothesis, (Tollenaar, et al. 2004) reported that heterosis for grain yield in maize can be attributed to (1) heterosis for dry matter accumulation prior silking as a result of effective light interception; (2) heterosis for dry matter accumulation during the grain filling period which is attributed to efficient light interception due to large leaf area index and increased stay green; and (3) heterosis for harvest index.

Relative potential photosynthesis for biological yield $\left(\mathbf{R P P}_{\text {bio.y }}\right)$ : Results given in Table 6 revealed that positive (desirable direction) highly significant relative superior percentages over commercial check hybrids SC Pioneer 3084 and SC 10 were recorded in six and seven crosses, respectively, under low $\mathrm{N}$ conditions. The highest percentages were recorded by cross no. 7 (B73X TZI8) (60.94\% over SC3084 and $83.22 \%$ over SC 10) followed by cross no. 6 (B73X CML103) (45.87\% over SC3084 and $66.06 \%$ over SC 10). Under normal $\mathrm{N}$ conditions, ten and eight crosses showed positive significant relative superior over both commercial hybrids SC Pioneer 3084 and SC 10, respectively. Cross no.7 (B73X TZI8) gave the highest estimates of relative superior $(86.17 \%$ over SC3084 and $71.17 \%$ over SC 10$)$ followed by cross no. 11 (B73X Sids63) (68.84\% over SC 3084 and $55.24 \%$ over SC 10$)$.

Relative potential photosynthesis for straw yield $\left(\mathbf{R P P}_{\text {s.y }}\right)$ : Results given in Table 6 revealed that positive (desirable direction) highly significant relative superior percentages over commercial check hybrids SC Pioneer 3084 and SC 10 were recorded in three and four crosses, respectively, under low $\mathrm{N}$ conditions. The highest percentages were recorded by cross no. 7 (B73X TZI8) $(47.30 \%$ over SC3084 and $60.14 \%$ over SC 10$)$ followed by cross no. 8 (B73X NC358) (29.79\% over SC3084 and $41.10 \%$ over SC 10$)$. Under normal $\mathrm{N}$ conditions, eight and nine crosses showed positive significant relative superior over both commercial hybrids SC Pioneer 3084 and SC 10, respectively. Cross no.7 (B73X TZI8) gave the highest estimates of relative superior $(95.07 \%$ over SC3084 and $108.90 \%$ over SC 10) followed by cross no. 11 (B73X Sids63) (56.91\% over SC3084 and $68.03 \%$ over SC 10). Results of Harsh and Sarkar (1992) confirmed extensive relative superior in photosynthetic rate and other photosynthetic related parameters which, in turn, were also reflected in higher biomass accumulation and yield. However, increased leaf photosynthesis alone did not induce higher grain yield. 
Table (6) : Estimates of relative superior over commercial varieties (SC Pioneer 3084 and SC 10) of $13 F_{1}$ single crosses for relative potential photosynthesis for biological and straw yield $\left(\mathbf{R P P}_{\text {bio.y }}\right.$ and $R_{P P} P_{\text {st.y }}$ ) under low and normal nitrogen conditions.

\begin{tabular}{|c|c|c|c|c|c|c|c|c|}
\hline \multirow[t]{3}{*}{ Traits } & \multicolumn{4}{|c|}{$\begin{array}{l}\text { Relative potential photosynthesis } \\
\text { for biological yield }\left(\text { RPP }_{\text {bio.y }}\right)\end{array}$} & \multicolumn{4}{|c|}{$\begin{array}{l}\text { Relative potential photosynthesis } \\
\text { for straw yield (RPPS.Y ) }\end{array}$} \\
\hline & \multicolumn{2}{|c|}{ Low $\mathbf{N}$} & \multicolumn{2}{|c|}{ Normal N } & \multicolumn{2}{|c|}{ Low N } & \multicolumn{2}{|c|}{ Normal N } \\
\hline & SC 3084 & SC10 & SC 3084 & SC10 & SC 3084 & SC10 & SC 3084 & SC10 \\
\hline 1-B73X PHG47 & $35.90^{* *}$ & $54.71^{\star \star}$ & $43.26^{\star *}$ & $31.72^{* *}$ & 1.56 & 10.41 & 9.63 & $17.40^{*}$ \\
\hline 2-B73X B97 & $22.91^{\star \star}$ & $39.92^{\star \star}$ & $37.99^{\star \star}$ & $26.87^{\star \star}$ & 7.80 & $17.20^{*}$ & $25.00^{\star \star}$ & $33.86^{\star *}$ \\
\hline 3-B73X PHJ40 & -4.38 & 8.86 & $20.01^{\star \star}$ & 10.34 & -8.94 & -1.00 & $13.01^{*}$ & $21.02^{* *}$ \\
\hline 4-B73X PH207 & $17.75^{\star}$ & $34.05^{\star *}$ & $35.56^{\star *}$ & $24.64^{\star *}$ & 4.54 & 13.65 & $19.12^{\star *}$ & $27.56^{\star *}$ \\
\hline 5-B73X HP301 & -13.96 & -2.05 & 1.37 & -6.80 & 4.04 & 13.11 & $14.63^{*}$ & $22.76^{\star *}$ \\
\hline 6-B73X CML103 & $45.87^{\star \star}$ & $66.06^{\star *}$ & $43.52^{* *}$ & $31.95^{\star *}$ & $21.21^{\star \star}$ & $31.77^{\star \star}$ & $20.37^{\star *}$ & $28.90^{\star *}$ \\
\hline 7-B73X TZI8 & $60.94^{\star *}$ & $83.22^{\star *}$ & $86.17^{\star \star}$ & $71.17^{\star \star}$ & $47.30^{\star *}$ & $60.14^{\star *}$ & $95.07^{* *}$ & $108.90^{\star *}$ \\
\hline 8-B73X NC358 & $43.19^{\star *}$ & $63.01^{* *}$ & $46.71^{* *}$ & $34.88^{* *}$ & $29.79^{\star \star}$ & $41.10^{\star *}$ & $29.41^{* *}$ & $38.58^{* *}$ \\
\hline 9-B73X MO17 & -3.70 & 9.63 & $18.49^{\star \star}$ & 8.94 & -13.47 & -5.94 & -8.75 & -2.28 \\
\hline 10-B73X Inb209 & $-15.61^{*}$ & -3.93 & -3.65 & -11.41 & $-14.82^{*}$ & -7.40 & $-14.78^{*}$ & -8.74 \\
\hline 11-B73X Sids63 & -3.55 & 9.80 & $68.84^{\star \star}$ & $55.24^{\star \star}$ & 4.04 & 13.11 & $56.91^{\star *}$ & $68.03^{\star *}$ \\
\hline 12-B73X Rg5 & 1.90 & $16.00^{*}$ & 10.69 & 1.77 & -10.92 & -3.16 & 0.15 & 7.24 \\
\hline 13-B73X Inb.204 & -0.83 & 12.90 & $25.38^{\star *}$ & $15.28^{*}$ & -10.36 & -2.54 & -1.47 & 5.51 \\
\hline LSD at 0.05 & \multicolumn{2}{|c|}{9.581} & \multicolumn{2}{|c|}{8.963} & \multicolumn{2}{|c|}{6.800} & \multicolumn{2}{|c|}{5.707} \\
\hline at 0.01 & \multicolumn{2}{|c|}{12.857} & \multicolumn{2}{|c|}{12.028} & \multicolumn{2}{|c|}{9.125} & \multicolumn{2}{|c|}{7.658} \\
\hline
\end{tabular}

${ }^{*}$ and ${ }^{* *}$ significant at 0.05 and 0.01 level of probability, respectively.

\section{Associated traits:}

Phenotypic correlation coefficients between grain yield plant ${ }^{-1}$ and the other studied vegetative and physiological traits are shown in Table 7. The phenotypic correlation coefficients were positive and highly significant (positive strong correlation) between grain yield plant ${ }^{-1}$ and each of biological yield plant ${ }^{-1}\left(r_{p h}=0.866^{\star \star}\right.$ and $\left.r_{p h}=0.843^{\star *}\right)$ under both low and normal $N$ levels, respectively, and relative potential photosynthesis for biological yield $\left(r_{\mathrm{ph}}=0.753^{\star *}\right)$ under low $\mathrm{N}$ condition, and were negative and highly significant (negative strong correlation) between grain yield plant ${ }^{-1}$ and ear leaf angle $\left(r_{p h}\right.$ $=-0.656^{* *}$ and $r_{p h}=-0.642^{* *}$ ) under both low and normal $N$ levels, respectively.

However, the phenotypic correlation coefficients were positive and significant (moderate correlation) between grain yield plant ${ }^{-1}$ and each of relative potential photosynthesis for straw yield $\left(r_{p h}=0.616^{*}\right.$ and $\left.r_{p h}=0.304^{*}\right)$, stem diameter $\left(r_{p h}=0.482^{*}\right.$ and $\left.r_{p h}=0.546^{*}\right)$ under both low and normal $\mathrm{N}$ levels, respectively, ear height $\left(r_{p h}=0.317^{*}\right)$ and ear position $\left(r_{p h}=0.359^{*}\right)$ under low $\mathrm{N}$ level, plant height $\left(r_{\mathrm{ph}}=0.325^{*}\right)$ and ear leaf area $\left(r_{\mathrm{ph}}=0.409^{*}\right)$ under normal $\mathrm{N}$ condition.

These results suggest that, in general, to increase grain yield plant ${ }^{-1}$, selection should be carried out for most of the studied vegetative traits, especially; biological yield plant $^{-1}$, low ear leaf angle (erect leaf), stem diameter (thick stalks), as well as for all physiological traits under both low and normal $\mathrm{N}$ conditions.

The magnitude of genotypic correlations of studied traits were higher than those of phenotypic and environmental correlation coefficients to ear 
yield, indicating that selection for these traits is expected to improve grain yield. These results were consistent with those by Spaner et al. (1996); Muraya et al., 2006; Bocanski, et al., (2009) and Aminu and Izge (2012).

Table 7: Phenotypic correlation coefficients between maize grain yield plant $^{-1}$ and the studied morpho-physiological traits under low and normal nitrogen conditions.

\begin{tabular}{|c|c|c|}
\hline \multirow{2}{*}{ Trait } & \multicolumn{2}{|c|}{ Grain yield plant $^{-1}$} \\
\hline & Low N & Normal N \\
\hline Plant height & 0.196 & $0.325^{\star}$ \\
\hline Stem diameter & $0.482^{*}$ & $0.546^{*}$ \\
\hline Ear height & $0.317^{*}$ & 0.246 \\
\hline Ear position & $0.359^{*}$ & 0.114 \\
\hline Ear leaf angle & $-0.656^{\star *}$ & $-0.642^{\star \star}$ \\
\hline Ear leaf area & 0.276 & $0.409^{*}$ \\
\hline Stay green \% & 0.033 & -0.088 \\
\hline Biological yield plant ${ }^{-1}$ & $0.866^{\star *}$ & $0.843^{\star *}$ \\
\hline \begin{tabular}{|ll} 
Relative potential photosynthesis for \\
biological yield $\left(\right.$ RPP $\left._{B . Y}\right)$
\end{tabular} & $0.753^{\star *}$ & $0.516^{*}$ \\
\hline $\begin{array}{l}\text { Relative potential photosynthesis for straw } \\
\text { yield (RPPS.Y) }\end{array}$ & $0.616^{*}$ & $0.304^{\star}$ \\
\hline
\end{tabular}

\section{Acknowledgement:} authors

This work was supported by a Mansoura University's award to the

\section{REFERENCES}

Abd El-Aty, M.S. and Y.S.Katta (2002). Estimation of relative superior and combining ability for yield and other agronomic traits in maize hybrids (Zea mays L.). J. Agric. Sci. Mansoura Univ., 27(8): 5137-5146.

Abdel-Moneam, M. A.; M.S. Sultan; S.E. Sadek and M.S. Shalof (2014). Estimation of relative superior and genetic parameters for some flowering and vegetative traits in maize using the diallel cross method. J. of Advances in Natural Scie., Vol. 2, No. 2, 157-166.

Al-Naggar, A.M.M., R. Shabana, M.M.M. Atta and T.H. Al-Khalil (2015). Regression of grain yield of maize inbred lines and their diallel crosses on elevated levels of soil-nitrogen. Int. J. Plant Soil Sci., 4: 499-512.

Aminu, D. and A.U. Izge (2012). Heritability and correlation estimates in maize (Zea mays L.) under drought conditions in Northern Guinea and Sudan Savannas of Nigeria. World J. of Agric. Sci. 8 (6): 598-602.

Banziger, M. and Diallo (2001). Progress and developing drought and $\mathrm{N}$ stress tolerant maize cultivars for Eastern and Southern Africa. $7^{\text {th }}$ Eastern and Southern Africa Regional Maize Conference, 11-15 Fbruary, Nairobi, Kenya. 
Bocanski, J.; Z. Sreckov and A. Nastasic (2009). Genetic and phenotypic relationship between grain yield and components of grain yield of maize (Zea mays L.). Genetika, Vol. 41, No. 2, 145-154.

Bruce, A.B. (1910). The Mendelian theory of heredity and the augmentation of vigor. Science 32: 627-628.

Collins, G.N. (1921). Dominance and vigor of first generation hybrids. Am. Nat. 55: 116-133.

Crow, J.F. (1948). Alternative hypotheses of hybrid vigor. Genetics 33: 477487.

East, E.M. (1908). Inbreeding in corn. pp. 419-428. Rep. Conn. Agric. Exp. Stn.

East, E.M. (1936). Relative superior. Genetics 21: 375-397

Edmeades, G. O.; J. Bolanos; S.C. Chapman; H.R. Lafitte and M. Banziger (1999). Selection improves drought tolerance in tropical maize populations. I. Gain in biomass, grain yield, and harvest index. Crop Science, 39, $1306-1315$.

Fehr, W.R. (1991). Principles of cultivar development. Theory and technique. MacMillan Publishing Co., 1: 536.

Fu, D.; M. Xiao A. Hayward; Y. Fu; G. Liu; G. Jiang and H. Zhang (2014a). Utilization of crop relative superior: a review. Euphytica 197:161-173.

Fu, D.; M. Xiao; A. Hayward; G. Jiang; L. Zhu; Q. Zhou and M. Zhang (2014b). What is crop relative superior: new insights into an old topic. $J$ Appl. Genet. 16

Györffy, B.-l'só, I.-Bölöni, I. (1965). Kukoricatermesztés. (Corn growing.) Mezőgazdasági Kiadó, Budapest.

Hallauer, A. R.-Miranda, J. B. (1981). Quantitative genetics in maize breeding. lowa St. Univ. Press, Ames, la.

Harsh M. and K. R. Sarkar (1992). Relative superior for leaf photosynthesis, grain yield and yield components in maize. Euphytica, 61(2):161-168.

Hochholdinger, F. and N. Hoecker, (2007). Towards the molecular basis of relative superior. TRENDS in Plant Science Vol.12 No.9

Hull F.H. (1945). Recurrent selection for specific combining ability in corn. J. Am. Soc. Agron. 37: 134-145.

Kazem Ghassemi-Golezani, Z. T. (2012). Relationship of plant biomass and grainfilling with grain yield of maize cultivars. Int. J. Agric. Crop Sci. Vol., 4 (20), 1536-1539

Keeble F. and C. Pellew (1910) The mode of inheritance of stature and of time of flowering in peas (Pisum sativum). J. Genet. 1: 47-56

Langade D. M., A. Singh and J. P. Shahi ( 2013). Appraisal of relative superior for yield and yield attributing components in maize (Zea mays L.). Biolife, Vol 1, (3): 123-129.

Leyla Cesurer ; T. Dokuyucu and A. Akkaya (2002). Understanding of Relative superior, University of Nebraska-Lincoln, Dept. of Agronomy, Horticulture KSU. Agriculture of Faculty, Department of Field Crops, Kahramanmaraş. (C.F. Computer Search). 
Logrono, M.L. and J.E. Lothrop (1996). Impact of drought and low nitrogen on maize production in Asia. pp. 39 - 43. In: G.O.Edmeades et al. (eds.), Developing Drought- and Low N-Tolerant Maize. Proceedings of a Symposium, March 25 - 29, 1996. CIMMYT, El Batan, Mexico.

Loomis R.S. and D.J. Connor (1992) 'Crop ecology: productivity and management in agricultural systems.' (Cambridge University Press:Cambridge)

Malvar, R. A.; A. Ordas; P. Revilla and M. E. Cartea (1996). Estimates of genetic variances in two Spanish populations of maize. Crop Sci. 36. 291-295.

Muraya, M. M.; C. M. Ndirangu and E. O. Omolo (2006). Relative superior and combining ability in diallel crosses involving maize (Zea mays) S1 lines. Australian J. of Experimental Agric. 46, 387-394

Pendleton, J.W.; G.E. Smith; S.R. Winter and T.J. Johnson (1968). Field investigations of the relationship of leaf angle in corn (Zea mays L.) to grain yield and apparent photosynthesis. Agronomy J. 60, 422-424.

Pilar, S.; B. Ordàs ; R.A. Malvar ; P. Revilla, and A. Ordàs (2006). Combining abilities and relative superior for adaptation in flint maize populations. Crop Sci., 46 : 2666-2669.

Raun, W. R. and G. V. Johnson (1999). Improving nitrogen use efficiency for cereal production. Agron. J., 91:357-363.

Reddy, D. M. and V. P.Ahuja (2004) Relative superior studies over environments for grain yield and its components in maize (Zea mays L.). National J. of Plant Improvement. 6: 1, 26-28.

Reif, J.C., S. Hamrit, M. Heckenberger, W. Schipprack, M. Bohn and A.E. Melchinger (2005). Trends in genetic diversity among European maize cultivars and their parental components during the past 50 years. Theor. Appl. Genet. 111: 838-845.

Richey, F.D. (1942). Mock-dominance and hybrid vigor. Science 96: 280-281.

Saleh, G.B.; D. Abdullah and A.R. Anuar (2002). Performance, relative superior and heritability in selection tropical maize single, double and three-way cross hybrids. The J. of Agric. Sci., 138: 21-28.

Schnable, P., and N. M. Springer, (2013) Progress Toward Understanding Relative superior in Crop Plants, Annual Review of Plant Biology Vol. 64: 71-88.

Schnell F.W. (1961) Relative superior and inbreeding effect. Schriftenreihe des Max-Planck-Instituts für Tierzucht und Tierernährung, pp. 251-272.

Schnell F.W. and C.C. Cockerham (1992). Multiplicative vs. arbitrary gene action in relative superior. Genetics 131: 461-469.

Shalim uddin M., firoza khatun, s. ahmed, m. r. ali and shamim ara bagum (2006). Relative superior and combining ability in corn (Zea mays L.). Bangladesh J. Bot. 35(2): 109-116.

Shull, G.H. (1908). The composition of a field of maize. Am. Breed. Assoc. Rep. 4:296-301. 
Shull G.H. (1909). A pure line method of corn breeding. Am. Breed. Assoc. Rep. 5: 51-59.

Shull G.H. (1952). Beginnings of the relative superior concept. pp. 14- 48. In: J.W. Gowen (Ed.), Relative superior. lowa State College Press, Ames, IA.

Spaner D, Brathwaite RAI, Mather DE (1996) Diallel study of open pollinated maize varieties in Trinidad. Euphytica 90, 65-72.

Sticker, F. C. (1964). Row width and plant population studies with corn. Agron. J., 56: 438-441.

Stupar, R.M. and N.M.Springer (2006) Cis-transcriptional variation in maize inbred lines B73 and MO17 leads to additive expression patterns in the F1 hybrid. Genetics 173, 2199-2210.

Tollenaar, M.; A. Ahmadzadeh, and E. A. Lee (2004). Physiological basis of relative superior for grain yield in maize. Crop Science, Vol. 44, 20862094

Vidovič, J. and V. Pokorný (1973). The effect of different sowing densities and nutrient levels on leaf area index, production and distribution of dry matter in maize (Zea mays L.). Biologia Plantarum, Volume 15, Issue 6, (11): pp 374-382

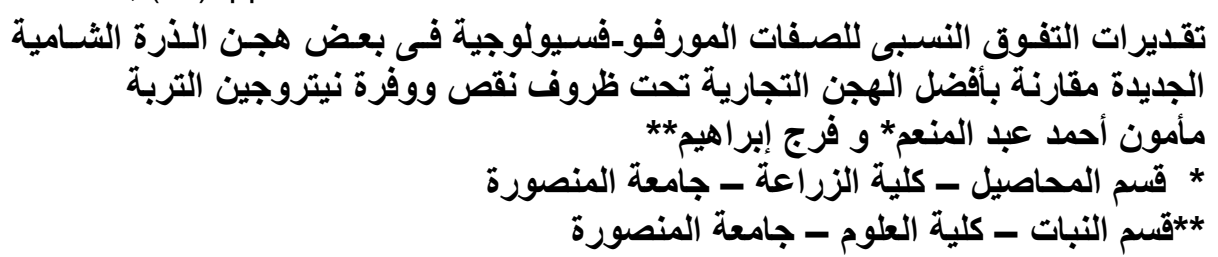

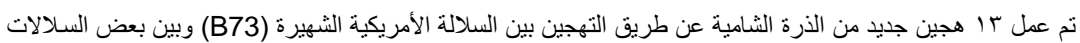

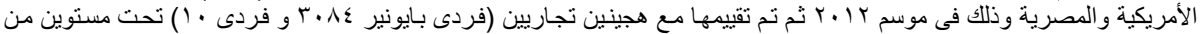

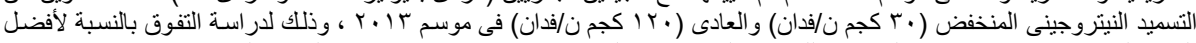

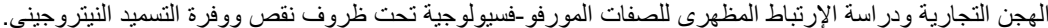

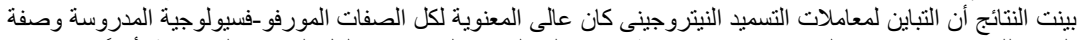

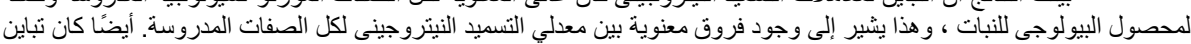

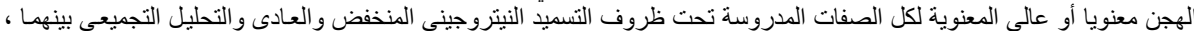

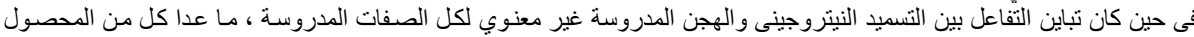

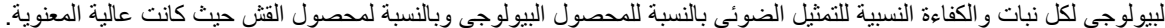

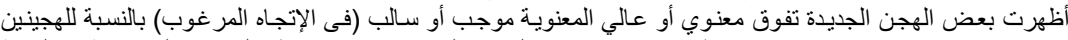

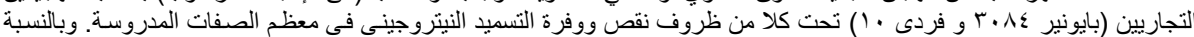

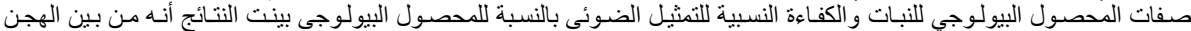

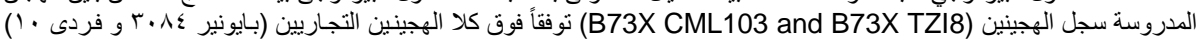

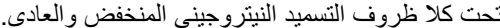

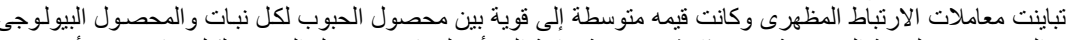

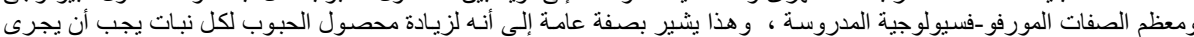

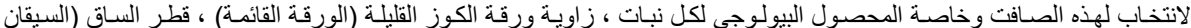

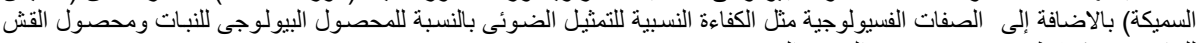
اللنبات تحت كلا ظروف نقص ووفرة التسميد النيتروجينى.

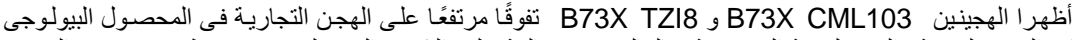

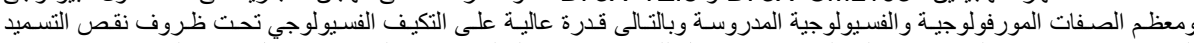

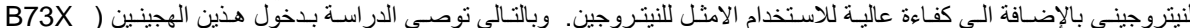

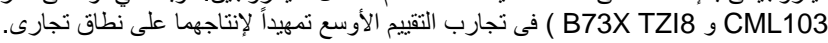

